\title{
Langerhans cell histiocytosis on the penis: a case report Jun Hagiuda ${ }^{1}$, Munehisa Ueno ${ }^{1}$, Satoshi Ashimine ${ }^{1}$, Isao Kuroda*1, Keisuke Ishizawa ${ }^{2}$ and Nobuhiro Deguchi ${ }^{1}$
}

Address: ${ }^{1}$ Department of Urology, Saitama Medical University, Saitama, Japan and ${ }^{2}$ Department of Pathology, Saitama Medical University, Saitama, Japan

Email: Jun Hagiuda - junhagi@ hotmail.com; Munehisa Ueno - camtmune@saitama-med.ac.jp; Satoshi Ashimine - mine@saitama-med.ac.jp; Isao Kuroda* - veq01625@nifty.ne.jp; Keisuke Ishizawa - ishizawa@saitama-med.ac.jp; Nobuhiro Deguchi - ndeguchi@saitama-med.ac.jp

* Corresponding author

Published: II October 2006

BMC Urology 2006, 6:28 doi:10.1 I86/147|-2490-6-28

This article is available from: http://www.biomedcentral.com/I47I-2490/6/28

(c) 2006 Hagiuda et al; licensee BioMed Central Ltd.

This is an Open Access article distributed under the terms of the Creative Commons Attribution License (http://creativecommons.org/licenses/by/2.0), which permits unrestricted use, distribution, and reproduction in any medium, provided the original work is properly cited.
Received: 24 May 2006

Accepted: II October 2006

\begin{abstract}
Background: Langerhans cell histiocytosis affects mainly young children and features an accumulation of CDIa+ dendritic Langerhans cells in the bone, skin, and other organs. A few cases of Langerhans cell histiocytosis on the penis have been reported in the literature. We present a case of Langerhans cell histiocytosis on the penis and review the similar cases in the literature.

Case presentation: The patient was a 13-year-old boy who had a history of lymph node, femur bone, and pituitary-thalmic axis lesions from Langerhans cell histiocytosis who noticed a painful nodule on the prepuce of his penis. The histological and immunohistochemical examination fulfilled the criteria of Langerhans cell histiocytosis.
\end{abstract}

Conclusion: We herein describe the case reported of Langerhans cell histiocytosis on the penis.

\section{Background}

Langerhans cell histiocytosis (LCH) is characterized by an organ-specific infiltration of cells with many morphological features and immunohistochemical markers of Langerhans cells. Clinically, LCH ranges from self-healing lesions to a multi-system involvement with organ dysfunction resistant to current therapies. The lesions appear in multiple organs, for example in the bones, skin, and lungs, but a lesion localized on the penis is uncommon. We herein report a case of $\mathrm{LCH}$ on the penis.

\section{Case presentation}

A 13-year-old boy presented with a nodular lesion on the prepuce of his penis. A diagnosis of $\mathrm{LCH}$ had been made at the age of 3 years. The first lesion was on a cervical lymph node. After the administration of chemotherapy with vincristine, cyclophosphamide, and predonisone, the lesion resolved. When the patient was 11 years old, he restarted chemotherapy (cyclophosphamide and 6-mercaptopurine) because of a recurrent lesion in the femur bone and along the pituitary-thalmic axis. At this time, he noticed a painful nodule, $5 \mathrm{~mm}$ in diameter, which was elastic, hard, and reddish, with a smooth surface (Fig. 1). Surgical resection of the nodule in the foreskin, without amputation or circumcision, was performed. Histologically, the lesions consisted of diffuse infiltrates of Langerhans cells with indented or grooved nuclei and eosinophilic or pale cytoplasm. Also present were various numbers of eosinophils, lymphocytes, and neutrophils. The lesions represented stromal edema and mild fibrosis. Their surface was focally eroded. Scattered vascular proliferation was present (Fig. 2). Both S-100 protein and CD1a were immunoreactive in the majority of these Langerhans cells (Fig. 3, 4). These findings led to a diagnosis of $\mathrm{LCH}$ 
of the penis. An additional treatment with oral and ointment steroid was given, and the patient was well throughout a 4-month follow-up, showing no signs of other lesions.

\section{Conclusion}

Histiocytosis X, which included Letterer-Siwe's disease, Hand-Shuller-Christian's disease, and eosinophilic granuloma, was renamed Langerhans cell histiocytosis in 1985 by the Histiocytic Society [1]. The diagnosis of LCH has been based on a histopathological pattern in biopsy specimens showing mono- or multinucleated Langerhans cells, histiocytes, and eosinophils. The presence of Birbeck granules on electron microscopic examination or of antigenic markers that react with CD1a glycoprotein and the cytoplasmic protein S100 detected by immunostain is considered diagnostic, as shown in the present case. LCH lesions are common in the bone, lung, skin, liver, spleen, and lymph nodes. In $30.6 \%$ of patients, LCH involved more than one body system. Twenty-five percent of patients had skin and/or mucous membrane LCH. The most common mucous membranes involved are the genitalia and oral mucous [2]. In the current literature, we found only 6 cases of a penile lesion, reported by Myers $e t$ al. [3], Caputo et al. [4], Yokota et al. [5], Meehan et al. [6], Seseke F et al. [7], and Maekawa et al. [8], respectively. Each case was treated by surgical excision, chemotherapy, or steroid ointment, and there are no reports in the literature of recurrence on the penis. Although treatment of vulvar lesions with radiation and surgical excision did not prevent recurrence [9], penile lesions appear to be too sensitive for this type of treatment. In a prior report, distinct Langerhans cell preponderance is shown in the transformation zone of the cervix and the vulva. Langerhans cells are modulated actively in response to certain chemical stimuli, human papillomavirus infection, and cervical

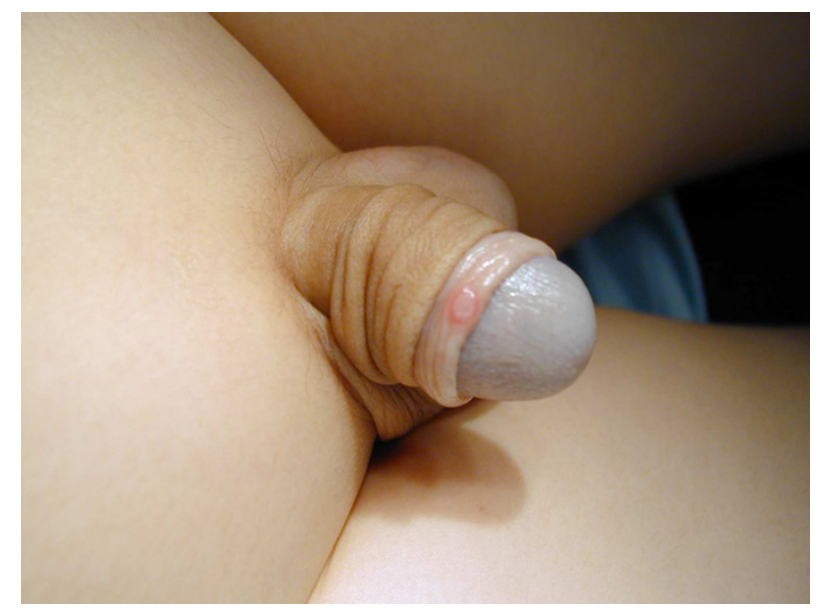

Figure I

Painful nodule on the prepuce of the penis.

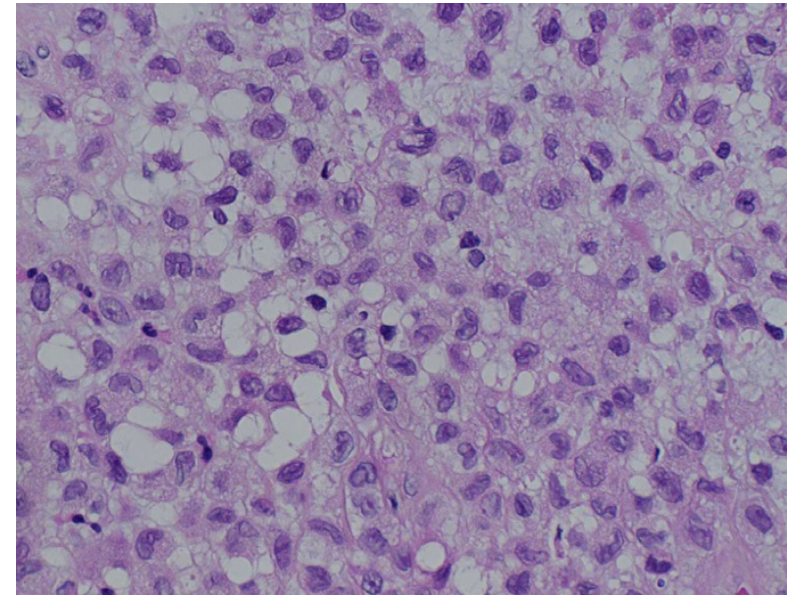

Figure 2

High-power view showing mononuclear Langerhans cells. The irregular nuclei have prominent grooves and folds. Numerous eosinophils can also be seen. Hematoxylin and eosin staining $\times 400$.

intraepithelial neoplasia [6]. It is not proven that the distribution of Langerhans cells or various stimuli to the penis may be related to the rare nature of penile lesions or the good response to the treatment. In the adult cases, there are sole cutaneous involvements of the penis. These cutaneous lesions in adult life may simply represent a limited form of LCH with an excellent prognosis. It is also possible that such lesions are the initial presentation of one of the multi-system instances of LCH [6].

Patients with localized LCH may have a good chance of spontaneous remission and a favorable outcome over a period of months to years [10]. The important factors for

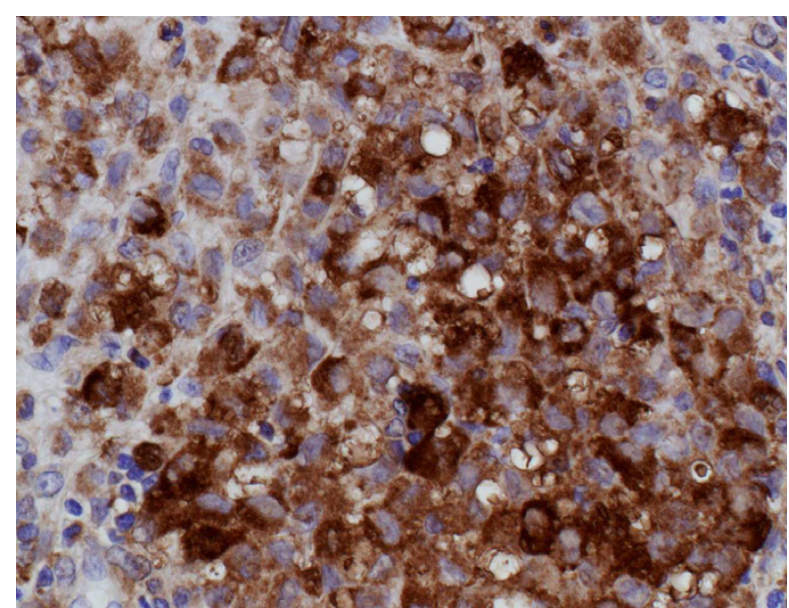

\section{Figure 3}

Note membranous immunoreactivity of S- 100 protein and $\mathrm{CDI}$ a in the majority of the Langerhans cells. $\times 400$. 


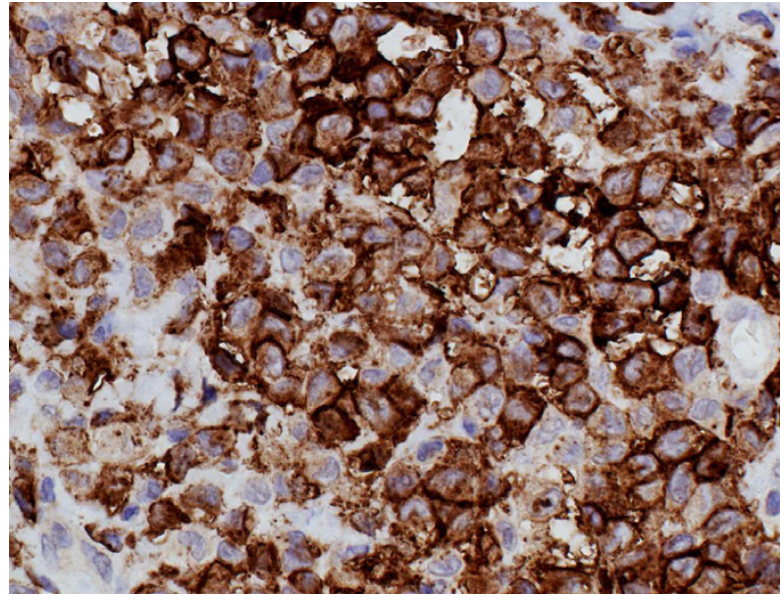

Figure 4

Note membranous immunoreactivity of S- 100 protein and $\mathrm{CDI} \mathrm{a}$ in the majority of the Langerhans cells. $\times 400$

predicting recurrent disease and poor prognosis include $\mathrm{LCH}$ involving both bone and mucocutaneous tissue, LCH involving both osseous and extraosseous tissues, relapse after treatment of patients with osseous $\mathrm{LCH}$ and multi-systemic LCH, >3 bones involvement, the presence of mucous membrane $\mathrm{LCH}$, the presence of hepatosplenomegaly in patients $<3$ years of age at presentation, pituitary-thalamic axis $\mathrm{LCH}$ in the presence of multi-systemic LCH, young age ( $<5$ years) at presentation, and $\mathrm{LCH}$ involving 3 or more body systems [2]. This patient had presented LCH at 3 years old and had already relapsed after the treatment for 3 lesions when the penile lesion appeared. Because this may indicate poor prognosis, we will continue to follow the patient closely, to watch for the development of any additional lesions.

\section{Competing interests}

The author(s) declare that they have no competing interests.

\section{Acknowledgements}

We thank the patient for giving consent for publication of this case report.

$\mathrm{JH}$ designed this case report and drafted the manuscript. SA and IK carried out the operation of this patient and helped to draft the manuscript. MU and ND participated in the design of the study and helped to draft the manuscript. KI carried out the pathological examination. All authors read and approved the final manuscript.

\section{References}

I. Writing Group of the Histiocyte Society: Histiocytosis syndromes in children. Lancet 1987, I(8526):208-9.

2. Howarth DM, Gilchrist GS, Mullan BP, Wiseman GA, Edmonson JH, Schomberg PJ: Langerhans cell histiocytosis; diagnosis, natural history, management, and outcome. Cancer 1999, 85:2278-90.

3. Myers DA, Strandjord SE, Marcus RB Jr: Histiocytosis $X$ presenting as a primary penile lesion. J Urol 198I, I 26:268-9.

4. Caputo R, Gianotti R, Monti M: Nodular 'pure' mococutaneous histiocytosis $\mathbf{X}$ in an adult. Arch Dermatol 1987, I 23: | 274-1275.
5. Yokota T, Aga Y, Miki H, Oomori M: A case of histiocytosis $\mathbf{X}$ of the penis. Jpn J Urol 1990, 81 : 1904-7.

6. Meehan SA, Smoller BR: Cutaneous Langerhans cell histiocytosis of the genitalia in the elderly: A report of three cases. J Cutan Pathol 1998, 25:370-374.

7. Seseke F, Kugler A, Hermanns M, Zoller G, Kallerhoff M, Ringert RH: Langerhans cell histiocytosis of the penis. Urologe 1999 , 38:42-45.

8. Maekawa $\mathrm{Y}$, Kogushi $\mathrm{H}$ : A case of Langerhans cell histiocytosis on the foreskin and external auditory meatus. J Pediat Dermatol 2004, 23:35-38.

9. Singh A, Prieto V, Czelusta A, Czelusta A, McClain K, Duvic M: Adult Langerhans cell histiocytosis limited to the skin. Dermatology 2003, 207:|57-|6|.

10. Velez-Yanguas MC, Warrier RP: Langerhans cell histiocytosis. Orthop Clin North Am 1996, 27:615-23.

\section{Pre-publication history}

The pre-publication history for this paper can be accessed here:

http://www.biomedcentral.com/1471-2490/6/28/prepub Publish with Bio Med Central and every
scientist can read your work free of charge

"BioMed Central will be the most significant development for disseminating the results of biomedical research in our lifetime. "

Sir Paul Nurse, Cancer Research UK

Your research papers will be:

- available free of charge to the entire biomedical community

- peer reviewed and published immediately upon acceptance

- cited in PubMed and archived on PubMed Central

- yours - you keep the copyright
BioMedcentral 